InOdia $\quad \begin{aligned} & \text { InMedia } \\ & \text { The French Journal of Media Studies }\end{aligned}$

$2 \mid 2012$

Performing/Representing Male Bonds

\title{
Midlife Pop Masculinities in the Here and Now
}

Chris Tinker

\section{(2) OpenEdition}

Journals

Electronic version

URL: http://journals.openedition.org/inmedia/444

DOI: 10.4000/inmedia.444

ISSN: 2259-4728

\section{Publisher}

Center for Research on the English-Speaking World (CREW)

\section{Electronic reference}

Chris Tinker, "Midlife Pop Masculinities in the Here and Now», InMedia [Online], 2 | 2012, Online since 06 December 2012, connection on 07 September 2020. URL : http://journals.openedition.org/inmedia/ 444 ; DOI : https://doi.org/10.4000/inmedia.444

This text was automatically generated on 7 September 2020

(c) InMedia 


\title{
Midlife Pop Masculinities in the Here and Now
}

\author{
Chris Tinker
}

1 The UK, like other Western countries, has witnessed in recent years an increase in popular music nostalgia with a particular focus on the 1980s. 2001 saw the launch of the Here and Now show by the promoter Tony Denton, following his earlier shows, which featured musicians associated with the 1970s, known as The Best Disco in Town. In 2011 Here and Now celebrated its tenth anniversary with a line-up including Boy George, Jason Donovan, Jimmy Somerville, Belinda Carlisle, Midge Ure, the duo Pepsi and Shirlie and the band A Flock of Seagulls. The show features a number of sets by individual artists and groups who perform their greatest hits rather than new material. ${ }^{1}$ Over the years the line-up has changed regularly while the number of individual acts featured has varied. Here and Now has been staged as a series of arena tours as well as single events in large indoor and outdoor venues, and has developed an international profile, including dates in Australia, Germany, Hungary, Ireland, Japan, Portugal and Switzerland. ${ }^{2}$ The show has also generated regular coverage in the British national, regional and local press, providing a mix of entertainment and human interest ${ }^{3}$ for what Marion Leonard terms "a broad base of readers" rather than "niche" audiences associated with the specialized music press. ${ }^{4}$ As Leonard observes, press coverage also serves as a promotional tool and "frames the public and artistic personas of musicians." ${ }^{5}$ Interviews, in particular, may be "understood as performances rather than moments where the 'real' or 'true' person behind the star persona is revealed." 6

2 The coverage of musicians in the press may have significant implications in terms of gender. For example, Leonard considers in her 2007 study of gender, rock and the music industry how the "notion of mental torment is used in reviews of male musicians to construct a profile of the tortured romantic artist and how in other examples, associations with mental ill health are called upon by journalists to 'dismiss' or 'other' female performers." 7 While the relationship between masculinities and popular music has been extensively examined in Freya Jarman-Ivens' 2007 edited volume, and her own chapter highlights the narratives of "degenerating" and "neutered" masculinity 
associated with the middle-aged Elvis Presley, the issue of midlife masculinities remains to be explored in greater depth. As this article will show, the press coverage of male pop musicians taking part in the Here and Now shows (October 2001- July 2011), notably Boy George (George O'Dowd, 1961-), Rick Astley (1966-), and Jason Donovan (1968-) provides a distinct set of midlife representations suitable for analysis. ${ }^{8}$ Although newspaper coverage of Here and Now features reference to and comment from other male artists associated with the 1980s including Nik Kershaw, Jimmy Somerville, Midge Ure and Paul Young, issues of midlife are particularly prominent in press coverage of Boy George, Astley and Donovan. To use P. David Marshall's terms, the well-established "celebrity status" of Boy George, Astley and Donovan "confers" upon them "a certain discursive power" where midlife masculinities are concerned: "within society the celebrity is a voice above others, a voice that is channelled into the media systems as being legitimately significant."

Boy George, Astley and Donovan all came to prominence in the UK during the 1980 s. Boy George achieved mainstream success in 1982 as the lead singer of the band Culture Club, having contributed to the development of the New Romantic scene with its "gendered ambiguity" 10 and "feminized masculinity." ${ }^{11}$ However, as Laurence Senelick comments, "While gender was being outraged" during the early 1980s, "sexuality remained opaque, a carefully guarded precinct of privacy." ${ }^{12}$ Indeed, in 1983 at a time when the mainstream media in the UK was much less enlightened where the question of homosexuality was concerned, Boy George famously evaded questions regarding his sexuality stating in an interview that he "preferred a cup of tea to sex." ${ }^{13}$ Following the initial break-up of Culture Club in 1986, Boy George pursued a career primarily as a solo vocalist and club DJ, and has also developed over the years a visible and activist gay identity.

Rick Astley launched a pop career in 1987 as part of the Stock, Aitken and Waterman (SAW) 'hit factory' of singers following his discovery by the music producer Pete Waterman. The following year, Jason Donovan, a former star in the Australian soap opera Neighbours, joined the SAW stable. Both Astley and Donovan were cast in quite conventional heterosexual terms as romantic boy-next-door types who would appeal to teenage girls. This was reflected strongly in their musical output. Astley scored chart success with "Never Gonna Give You Up," "Whenever You Need Somebody," "Together Forever," and "When I Fall In Love" (a cover of the Nat King Cole classic), while Donovan's hits included "Nothing Can Divide Us," "Too Many Broken Hearts," "Sealed With A Kiss," a cover of Bryan Hyland's 1962 hit, and "Especially for you," a duet with his Neighbours co-star and fellow SAW artist Kylie Minogue. Television viewers had indeed previously been gripped by the on-screen romance between the characters that Donovan and Minogue played in the soap.

5 Following his success with SAW, Donovan went on to develop further his career in acting, singing and radio DJing. In 1990 Astley changed record company and direction, wishing to develop further his profile as a singer-songwriter as well as his longstanding interest in soul music, and in 1993 decided to retire as a performer to spend more time with his wife and young daughter. In 2008 Astley's media profile was given an unexpected boost when he became the subject of the 'Rickrolling' craze, an Internet meme/prank in which unsuspecting web surfers were tricked into watching his 1987 music video of "Never Gonna Give You Up." 
6 Over the years the popular media has charted the ups and downs in the personal lives of Donovan and Boy George and particularly their struggle to overcome drug addiction as well as their legal difficulties, for example, Donovan's successful libel action against The Face magazine for claiming that he was gay, which was said to have had a detrimental effect on his career at the time; ${ }^{14}$ and Boy George's 2006 community service in New York for drug possession and, in the UK, his 2009 prison sentence for false imprisonment of an escort (which led to his replacement in the Here and Now line-up by Rick Astley).

7 Newspaper interviews with Boy George, Donovan and Astley, which reflect their participation in the Here and Now show, exhibit a range of approaches to masculinity and midlife. While traditional masculinities are maintained in terms of rationality and developed through discourses of midlife maturity, they are also challenged through the importance attached to emotion and sensitivity, a reduction in work-related competitiveness and the expression of a more detached, light-hearted, even flippant, attitude. Finally, certain 'new' masculinities, which gained currency during the 1980s, are in evidence, particularly the emphasis on fathers-as-nurturers and on equality in heterosexual partnerships.

\section{Rationality and Maturity}

8 Traditional masculinities are maintained in newspaper coverage particularly in terms of rationality and self-control. Donovan expresses a need to "draw the line" under the 1980s, "move on," and look to the future after re-connecting with the decade briefly during the Here and Now shows. ${ }^{15}$ Astley is presented within the context of the show as an artist who has taken and still retains control over his personal life and career, which was "once meticulously managed by the Hit Factory of Stock Aitken and Waterman, but is now firmly back in his own grasp"; "these days Rick's work schedule is very much on his own terms". ${ }^{16} \mathrm{He}$ regards his participation in the show in conscious, calculated, and detached terms as a "weekend job"; "17 "It's a bit like turning it on and turning it off"; ${ }^{18}$ "This has nothing to do with my life." ${ }^{19}$ Such a desire for control is not, however, limited to representations of male artists. Indeed, in newspaper coverage Toyah Willcox, a female member of the show line-up, recognizes her own power to shape her career. $^{20}$

9 Astley's own relationship with celebrity and anonymity is also presented in rational, controlled terms: "I've said you can't have it both ways but I kind of do"; "I'll come up to Liverpool and I'll do a gig and for that moment you're on stage you're famous again, then you walk off stage and you're not"; "I'll be driving down the M6 [motorway] and I'll go and fill up the car with fuel and not one person will recognise me." ${ }^{21}$ Astley's defence of his personal privacy in press coverage is presented as a strategy for maintaining the kind of 'normal' life that international 'icons' such as Madonna are no longer able to experience. ${ }^{22}$

10 Astley is represented as rational not only in the present but at earlier points during his career and life history. A controlled, at times, dispassionate approach is expressed towards his early career as a pop star: "I enjoyed the job I did and part of the trappings of fame which went with it. But I wanted to be able to turn fame on and off like a tap." 23 A desire for control is also cited by Astley as a reason for his decision to leave the limelight and 'retire' from the music business: "While I appreciated how lucky I was, it 
catapulted me into a completely new world and simply took over my life. When I realized it was turning me into someone I didn't like - doing something I didn't want to do - I decided to walk away." ${ }^{24}$

11 In one particular interview, Astley attempts to explain and rationalize his drive to perform and achieve recognition by looking back further in life to his childhood, attributing much of his and other people's drive for fame and subsequent withdrawal from the public eye to what he perceives as an atypical experience - his parents' separation, limited contact with his mother and a need for attention:

He had therapy to help him understand what had happened.[...] "When you look at people who've ended up performing one way or another, look at their childhood and very few of them come from a mum and dad, 2.2 kids and a Ford on the drive. There's usually a crack. [...] I even think, when performers fall off the wagon, often it's because of that twist within them that's made them want to perform." ${ }^{25}$

While coverage of Astley rationalizes his past life so as to develop an understanding of his life and career to date, coverage of Boy George and Donovan contributes towards a sense of optimism and purpose both in the present and in the future. In interview, Donovan expresses a clearer sense of selfhood and destiny, having succeeded in articulating his own uncertainties regarding his identity earlier in his career when he played the lead role in the Andrew Lloyd Webber musical Joseph and the Amazing Technicolor Dreamcoat:

When I looked at myself in a loin cloth and a fluffy coat I sort of thought is this really where I want to be? I was listening to Nirvana records and, you know, I wasn't that guy. [...] I wasn't Joseph and I wasn't Kurt Cobain. What I didn't realise was that I was me and I should have been proud of being me. It is sort of a psychological rebellion against success. [...] The great positive is that I now know what I don't want to do with my life. ${ }^{26}$ Similarly, Boy George discusses how he has regained control and calm in his life following his prison sentence: "'It was a major epiphany. I'd been waiting to go for trial for almost a year. I was thinking a lot about what was going on in my life, thinking: "Come on, I need more than this." The significance was that George realized he could take control." ${ }^{27}$ Control and precision are also evident in representations of Boy George's health regime and detoxification as he recalls the date he became free of alcohol and drugs. ${ }^{28} \mathrm{~A}$ particular feature of Boy George's more controlled and restrained persona is a calmer, simpler approach to life: "Now, I'm the person I should be. I cherish the moderate life now: I don't want drama or complication." ${ }^{29}$ Moreover, according to press coverage, Boy George seeks to curb his tendency to speak openly and honestly about other figures in the music and entertainment world such as the singersongwriter Elton John and the actor Matt Lucas, ${ }^{30}$ or about his personal relationships: "People ask me if I regret anything and there's nothing I lose sleep over, but I do sometimes wish I'd said less." ${ }^{11}$

Coverage attributes Boy George's self-control to the kind of "mature masculinity" that the psychologist and psychoanalyst Michael J. Diamond associates with men in early and later middle age..$^{32}$ This maturity reportedly informs Boy George's approach to the reunion of his band Culture Club as it prepares for its thirtieth anniversary album release and concerts: “I don't know what the album's going to be like, something kind of a bit more grown up. We're not going to try and wear trousers we wore when we were 20, we're not going to try and recreate anything. [...] a bit mature and elder statesmanlike." ${ }^{\prime 3}$ Boy George's new mature self comes as a clear contrast with his 
'former' younger self, who, in his own words, "was quite belligerent and selfdestructive." ${ }^{34}$ Temporal markers such as the thirtieth anniversary of Culture Club and Boy George's fiftieth birthday provide an opportunity to reflect on and underline the changes and improvements that he has made to his life. ${ }^{35}$ In interview, Boy George refers explicitly to the benefit of hindsight which informs his more moderate behaviour: "I'd love to be able to experience all that I did with the knowledge I've got now." ${ }^{36}$

While Boy George, Astley and Donovan all effectively review to varying degrees their own "life stories," to use Dan P. McAdams' term, ${ }^{37}$ the accounts of Boy George indicate a more distinct process of what Abigail Stewart (1996) terms "midlife correction," or as Cavanaugh and Blanchard-Fields put it, "reevaluating one's roles and dreams and making the necessary corrections." ${ }^{38}$ Rather than a 'normative' 'midlife crisis,' it is also more constructive to talk of progression towards what the psychiatrist Martin Kantor refers to within the context of gay midlife experience as "midlife competence" - a crisis with positive outcomes:

Though the term 'midlife crisis' implies an undesirable condition, a 'midlife crisis' can in fact be a positive event should it culminate in an epiphany and so become a time not of involution but of evolution, where new solutions to old problems develop; where ways of coping not formerly realized, acknowledged, or incorporated into a life plan newly evolve; and where as old pleasures vanish, new satisfactions take their place, leading to midlife competence enhanced, say, by the successful resolution of earlier crises, such as those associated with coming out and being rejected. ${ }^{39}$

While coverage of Boy George, Donovan and Astley maintains the traditional notion of masculinity as rational, other traditional masculinities are challenged, namely, to use the terms of Katie Milestone and Anneke Meyer, a "lack" of "sensitivity and emotions," the position of the male as "head of family and household," and the male who "primarily defines himself through his work." ${ }^{40}$ Indeed, competitiveness within the context of work is represented as decreasing in importance during midlife. In certain instances, this is accompanied by a heightened sense of detachment, if not flippancy, as performers appear increasingly reluctant to take themselves seriously.

\section{Emotionality}

20 Traditional masculinities are challenged in coverage via an emphasis on emotion and sensitivity. For Jason Donovan the Here and Now show allows him as well as audiences to engage emotionally: "Being associated with that period is great. It's an opportunity to reconnect with an emotional period in my life"; "Music is an incredibly emotional thing and it gives people great memories." ${ }^{41}$ It is, however, coverage of Boy George that particularly emphasizes the value of emotion and sensitivity through his reference to his own song repertoire:

21 I like the title of the tour: Songs That Make You Dance And Cry. A lot of my favourite music makes me dance and cry - hopefully at the same time! I just think that I work in those two fields. Either I'm being quite melancholy, with things like "Generations of Love," or quite joyous, with things like "Bow Down Mister". ${ }^{42}$

22 In addition, the emotional dimension of Boy George's musical output is effectively represented in coverage as an alternative to traditional heterosexual masculinities - he 
identifies his work with Culture Club in distinct terms as his "gay love songs." ${ }^{43}$ In interview, he also highlights the emotional qualities in the work of other artists, notably Amy Winehouse:

When I hear the music, it makes me feel something. It makes me sad; it makes me emotional. [...] she's expressing what a lot of us can't express - and that's the sign of a great singer. If you hear a song on the radio like "Love Is A Losing Game" or "You Know I'm No Good", and it touches your heart, you know that she's doing something right. ${ }^{44}$

For Boy George, Winehouse's emotional power contrasts with the work of other pop artists (such as "Don't Cha" by The Pussycat Dolls, 2005), which is "clever, it's witty, it's designed for radio - but there's no feeling in it.": "It's not about human relationships as they really are. It's a commercialised version." ${ }^{45}$

\section{Creativity and Levity}

In newspaper coverage of the three performers, "experiencing" work during midlife, to use Diamond's terms, "takes precedence over the excitement of striving and reaching." ${ }^{46}$ Astley's work is viewed strongly in terms of "enjoyment" 47 and the satisfaction that can be derived from the "tingle" experienced when playing music, ${ }^{48}$ "the camaraderie of the 80s tours, ${ }^{49}$ writing for movies, and playing music with a group of friends in a local band, the Luddites. ${ }^{50}$ The importance of creativity through work is also emphasized in coverage of Donovan: "I'm very lucky doing a job where I get to practise my craft every day, there's lots of people stuck behind desks"; "I think the most important thing for me is to be passionate about my craft, to care about singing." ${ }^{11}$ The importance that Boy George places on creativity is cited as a reason why he could not conceive of a Culture Club reunion tour without himself as singer: "It just proved to me once again that my motivation was entirely different to theirs [his band mates]. Because my thing is not about career; it's about creating things that I care about." ${ }^{52}$

The traditional masculine notion of work-related competition is also challenged in coverage. As Boy George comments in an article: "What's nice about these kinds of tours is that you get to work with these people when you're older and more settled. When you're 19 or 20, you think everything's a competition." ${ }^{53}$ Similarly Rick Astley observes how "the ego has gone out of it"; "We are all a bit more relaxed and chilled out about it and therefore having more fun." ${ }^{54}$ In interview, Donovan also expresses a relaxed approach which is attributed to ageing: "The older I get the less stressed out I get about these sort of things because I realize that noone's going to die and if they do then I'm in the wrong business!" ${ }^{55}$ Such a view is not limited to male interviewees in press coverage of Here and Now - female performers also highlight the camaraderie and relaxed, non-competitive atmosphere of the show..$^{56}$

In interview Astley exhibits a particularly strong sense of detachment from himself and his participation in the Here and Now show: "Honestly, there are times when I look at the audience and I'm thinking, 'What are you doing? What the bloody hell are you doing?" ${ }^{57}$ A similar sense of detachment (and ultimately dissatisfaction) is also expressed in his account of his television appearances during the height of his success:

Every country you go to has their funny bonkers Saturday evening show, and you're the guest and you come off and think, "What the hell was that?" In the end, I didn't 
even like myself. I used to look at myself and think, what the bloody hell are you doing? 58

Astley also refuses to take the renewed media and public attention seriously, dismissing the Best Act Ever at the MTV Europe Music Awards that he received in 2008 following the Rickrolling internet phenomenon as "ridiculous" and "daft," ${ }^{59}$ and regarding Here and Now as "hardly a serious show." ${ }^{60}$ Astley also expresses disengagement with the contemporary music industry and its long-established figures of authority: "I'm not relevant in that world anymore. I just think it's slightly embarrassing to throw U2 into that category and then you've got Bono there giving an award to Paul McCartney and somebody like me wins that..." ${ }^{61}$ Like Astley, Boy George exhibits a reluctance to take life too seriously, for instance in humorous comments which play on the strong association between his public persona and his well-known attention to visual style: "The veteran of countless tabloid stories, says he is far less concerned about what the press say about him than in his younger days [...] 'As long as the pictures are good, I couldn't care less what they write about me."'62 Such a desire not to take life too seriously is not, however, limited to representations of male artists. ${ }^{63}$ Indeed, Kim Wilde makes a nuanced distinction between performers not taking "themselves" too seriously and taking "what they do" seriously. ${ }^{64}$

\section{Generativity and Equality}

The traditional view of masculinity, which, according to Milestone and Meyer, sees a man "primarily define himself through his work" 65 is seen no longer to apply particularly in coverage of Donovan and Astley, which represents both as nurturers. ${ }^{66}$ As Diamond comments, this nurturing form of masculinity is particularly evident during midlife: "For most men, early and later middle age is the time when their nurturing and 'feminine' sides are more fully integrated into their notion of mature masculinity." ${ }^{67}$ Such nurturing may also be viewed as part of a broader phenomenon of generativity (Erik Erikson, 1982), which is also closely associated with midlife. As Cavanaugh and Blanchard-Fields comment,

31 The struggle occurs between a sense of generativity (the feeling that people must maintain and perpetuate society) and a sense of stagnation (the feeling of selfabsorption). Generativity is seen in such things as parenthood; teaching, [...]; or providing goods and services for the benefit of society. If the challenge of generativity is accepted, the development of trust in the next generation is facilitated, and the psychosocial strength of care is obtained. ${ }^{68}$

One report views Donovan in terms of domestic bliss (he "says he likes nothing better than ordinary chores and spending time with the family.") and British/English gardening stereotypes: "chart-topper Jason Donovan dreams about cutting his lawn."69 In her regular column the television presenter Lorraine Kelly congratulates Donovan on the birth of his third child..$^{70}$ Coverage also emphasizes Donovan's father-as-nurturer role, which is informed by his past drug addiction: "he hopes his experiences with drugs will help him guide his children later in life." 71

33 Astley is represented in terms of family life, domesticity and material wealth and comfort: "I define myself now as a dad with a Land Rover and a nice house and a nice, comfortable life and I'm lucky and that's about it." ${ }^{72}$ His decision to participate in the Japanese leg of the Here and Now show is influenced by his family who wished to 
accompany him. ${ }^{73}$ For Astley, the prioritization of family life is also emphasized by reaffirmation of his earlier decision to leave the music industry: "I wanted to be home with my lovely partner Lene and my new baby girl Emilie"; "74 "The decision came when he was so busy with work that he missed his daughter's first steps"; "75 "He's been around to watch her grow up, which matters to him enormously." 76

Coverage also challenges traditional masculinities by representing Astley's wife Lene Bausager in nurturing terms as an equal partner. ${ }^{77}$ In interview, Astley expresses clear support for his wife and her career following her nomination for an Oscar for her short film Cashback: "Lene had worked so hard and she deserved all the lunches with the nominees and it was important to me to support her."78

While the nurturing of children and/or partners is emphasized in coverage of Donovan and Astley, other family relationships are reinforced. Astley describes his parental family, based in Newton-le-Willows, as a "priority," particularly his mother who is credited with instilling within him a "love of music" and who joined him on stage to sing "When I Fall In Love" at a 2011 Haydock Park concert. ${ }^{79}$ In a lengthy 2011 article published in the Daily Mail by Spencer Bright, the co-writer of the first volume of Boy George's 1995 autobiography Take It Like A Man, the importance of Boy George's parental family, "his bedrock," is highlighted: "he admits that without them, he may not have survived." His mother is described as "amazing," while his brother and sister are viewed in close terms: "Today it's a scene of cosy domesticity as his sister Siobhan vacuums and his brother Kevin does some office work in the kitchen." Despite his problematic relationship with his late father, Boy George also retains "all the great things about my dad, little things like him singing in the car. Funny stuff, rather than all the turmoil. I think that's a good thing."

Newspaper coverage thus represents various forms of family nurturing which are attributable not only to the influence of the 'new man' but also to the phase of midlife, which, according to Diamond, is generally a time of increased "connection" with and "nurturance" of others. ${ }^{80}$

Newspaper coverage of Here and Now effectively reinforces the view of men and masculinities, to use the terms of Michael S. Kimmel, Jeff Hearn and Robert W. Connell, as "variable and changing across time (history)," ${ }^{81}$ maintaining and challenging traditional masculinities while incorporating 'new' masculinities and practices associated with midlife. Traditional masculinities are maintained via representations of rationality as well as control over the careers and lives of pop musicians. Such rationality is combined with an increased sense of "understanding" of "self, emotions and motivations" (Diamond) as well as "gains in cognitive complexity" (Cavanaugh and Blanchard-Fields) and "insight" (Diamond), as musicians look to the past as well as the present and future. Accounts of Boy George are particularly extensive in conveying a sense of midlife "correction" and "competence" rather than crisis. Traditional masculinities are challenged via emphasis on emotion and sensitivity, particularly in coverage of Boy George and Donovan. Such an increased understanding of emotions is indeed, as Cavanaugh and Blanchard-Fields suggest, a typical feature of midlife. Moreover, coverage conveys a decreasing sense of work-related competitiveness and an increasing reluctance to take life too seriously. New masculinities also figure via representations of gender equality within male-female relationships as well as images of the father-as-nurturer. In coverage, the family is viewed more generally as a 
nurturing environment by musicians. Indeed, such generativity is strongly associated with midlife.

The coverage of male midlife discussed in this article is something of a departure from the newspaper representations of men and men's practices noted in a 2001 European Commission study published in 2004. The study found that in various national contexts (Estonia, Finland, Germany, Ireland, Italy, Latvia, Norway, Poland, the Russian Federation and the UK) a high proportion of articles on men associated them with the perpetration of violence and crime. In addition, UK newspaper coverage foregrounded military masculinities via stories of bullying in the armed forces and associated men with scandals involving sexuality and violence. The study also highlighted a general lack of representations of men in family roles (fathers, sons, brothers etc.), which is clearly at odds with newspaper coverage of Here and Now. Nonetheless, the relatively strong emphasis on men's health in UK coverage highlighted by the study is to some extent echoed in references in the coverage of Boy George and Donovan to detoxification and healthier lifestyles. ${ }^{82}$

While contemporary press coverage of Boy George, Donovan and Astley may be understood in terms of an integrated approach to masculinity and midlife, further research might consider the extent to which representations of midlife masculinities are shaped by other identities, individual personality dimensions and traits, ${ }^{83}$ as well as the interaction between journalists and their interviewees. Indeed, as Leonard comments, "Little academic attention has [...] been given to the 'management' of interviews by musicians themselves." ${ }^{84}$ Midlife masculinities may also be compared across different media forms, print and audio-visual. Here and Now has, for example, generated television coverage, including interviews with performers like Boy George, Donovan and Astley on daytime magazine programmes such as Loose Women and This Morning (both on ITV1; examples in Bibliography), which seem to reproduce many of the themes and concerns identified in the present study. Cross-cultural comparisons of midlife masculinities would also help to account for differences between media cultures. For example, French newspaper coverage of RFM Party $80,{ }^{85}$ a successful $1980 \mathrm{~s}$ nostalgia tour in France, appears to concentrate more on discussing the significance of nostalgia as a cultural phenomenon than on relaying musicians' accounts of midlife, as seen in British coverage. While Here and Now provides a discrete case study and useful starting point for examining media representations of male musicians during midlife, further research could also usefully look beyond coverage of musicians associated with the show to include a wider range of figures who are still active performers and whose middle age has been or is currently being played out elsewhere in the media.

If we recognize that popular culture is an important vehicle for the mobilization of masculinities, and that, as Stuart C. Aitken comments, "Popular representations [...] are particularly powerful forums for displaying cultural ideals about masculinity," 86 then coverage of Boy George, Donovan and Astley effectively promotes a multi-faceted, 'competent' view of midlife masculinities, which is rational, mature, emotional, creative, insouciant, nurturing and egalitarian. 


\section{BIBLIOGRAPHY}

\section{Newspaper Articles (October 2001- July 2011)}

(Factiva database, accessed July 16 and 17, 2011)

Allen, Gavin. "Return of the one and only." South Wales Echo, April 7, 2009.

Anglesey, Natalie. “Family is Rick's priority.” Manchester Evening News, July 20, 2011.

Arnold, Stuart. "Critics.” The Northern Echo, December 18, 2004.

Atkinson, Mike. "Here And Now tour, Nottingham Trent FM Arena, Friday May 9." Troubled Diva, May 10, 2008. http://troubled-diva.com/2008_05_04_troubled-

diva_archive.html\#5885785463623772144 <accessed 13 August, 2012>.

Atkinson, Mike. “Interview: Boy George.” Nottingham Evening Post, January 9, 2009.

Bright, Spencer. "My life hasn't always been a disaster but when it has, it's been spectacular!"

Daily Mail, June 10, 2011.

Button, Simon. "Toyah Willcox is back on the road and singing new songs but that doesn't make her a has-been." The Express, February 11, 2002.

“Carole's life is on a roll." Sunday Mercury, October 7, 2001.

Coleman, Andy. “George not fazed by 50th birthday.” Birmingham Mail, June 24, 2011.

Collinson, Dawn. “The King of Rick 'n' roll.” Liverpool Echo, January 30, 2009.

Davis, Johnny. “Never Gonna Give You Up.” The Times, May 16, 2009.

Davis, Laura. "If you don't like it then just quit." Daily Post (Liverpool), April 3, 2009.

“Eg interview: Boy George." Nottingham Evening Post, February 1, 2008.

“Eg interview: Rick Astley." Nottingham Evening Post, April 4, 2008.

“Everything is still rosy in Donovan's garden." Solihull News, April 29, 2011.

Fletcher, Tim. “Drugs, prison, pop - and a boy that's finally grown up." Burton Mail, November 12, 2010.

Foster, Jill. “CD reviews and music: heaven to hell.” Daily Mirror, July 30, 2004.

Heawood, Sophie. “Are we ever gonna give him up?” The Times, January 30, 2009.

Henderson, Gail. “Gail Meets Jason Donovan.” The Sunday Life, November 7, 2010.

“Jason's Happy to Revisit the 80s.” Coventry Evening Telegraph, June 24, 2011.

Jones, Catherine. "Jason Donovan talks The War of the Worlds and takes a look back at the 80s." Liverpool Echo, November 19, 2010.

Kelly, Lorraine. “He'd Don So Well.” The Sun, October 9, 2010.

“Kim Wilde keeps hangin’ on.” Derby Evening Telegraph, February 20, 2009.

Michaels, Sean. “Boy George to reunite Culture Club in 2012." The Guardian, January 29, 2011.

“Never gonna give him up." Nottingham Evening Post, May 7, 2009.

“Never gonna regret giving up fame." Sunday Sun, February 24, 2008. 
Parkes, Diane. “Midge’s pledge to play his hits.” Birmingham Mail, 14 January, 2011.

Pinch, Emma. "I still get a tingle from singing." Daily Post (Liverpool), May 13, 2008.

Powlson, Nigel. “Rick's never gonna give up.” Derby Evening Telegraph, May 21, 2010.

Radnedge, Aidan. "Neighbour moves on; Jason Donovan puts the 80s behind him - after trip down memory lane." Metro, October 8, 2010.

Rennie, Jonathan. “Tony’s just an old romantic at heart.” Evening Times, April 18, 2002.

“Rick Astley writing movie musical." Guardian Unlimited, February 2, 2009.

Rimmer, Louise. 'It's a mystery but no new song required as the Eighties turns to gold." Scotland on Sunday, April 28, 2002.

"She's the real wilde child." Nottingham Evening Post, April 2, 2009.

“Showbiz: Rick pads up." Sunday Mercury, November 18, 2007.

Smith, Aidan. "Accepting the Eighties.” The Scotsman, July 18, 2011.

Varma, Anuji. “I’m sorry... by George.” Sunday Mercury, October 12, 2008.

Wilson, Simon. “Interview: Rick Astley.” Nottingham Evening Post, January 23, 2009.

Wilson, Simon. "Interview: Kim Wilde." Nottingham Evening Post, May 1, 2009.

Television Interviews (accessed May 22, 2012)

“Boy George full interview on This Morning - 31st January 2011." YouTube video, 6:50, from an interview televised by ITV1 on January 31, 2011. Posted by “spikeyroberto." February 1, 2011. http://www.youtube.com/watch?v=Dd4AmvU9VYM

"Boy George interview on Loose Women - 9th February 2011 (Wide)." YouTube video, 6:39, from an interview televised by ITV1 on February 9, 2011. Posted by "spikeyroberto." February 12, 2012. http://www.youtube.com/watch?v=KEcb0Z3oaOs

"Boy George on Loose Women 8th Oct 2010." YouTube video, 10:11, from an interview televised by ITV1 on October 8, 2010. Posted by "Sessomy." October 8, 2010. http://www.youtube.com/ watch?v=m7oApzigqbE

“Jason Donovan Live Interview 10th May 2011." YouTube video, 8:58, from an interview televised by ITV1 on May 9, 2011. Posted by “loveinthe80s1.” May 12, 2011. http://www.youtube.com/ watch?v=uaC3hK3Ehs0

"Loose Women: Jason Donovan." YouTube video, 8:22, from an interview televised by ITV1 on December 10, 2007. Posted by "myloosewomenchannel." June 6, 2008. http://www.youtube.com/ watch?v=-V1mZVvStJ4

“Rick Astley - BBC Interview 3/4/09." YouTube video, 3:50, from interview televised by BBC News on March 4, 2009. Posted by “AngelHeart741.” March 4, 2009. http://www.youtube.com/watch? $\mathrm{v}=$ mzKF9iqa-iw

"Rick Astley Interview - Live From Studio Five." YouTube video, 8:59, from an interview televised by Channel 5 on June 8, 2010. Posted by “Ryan915." June 8, 2010. http://www.youtube.com/ watch?v=erPIq-HxS7A

"Rick Astley interview on Richard \& Judy - part 1 ." YouTube video, 7:20, from an interview televised by Watch on March 5, 2009. Posted by “sexteta." March 9, 2009. http:// www.youtube.com/watch?v=gOVeqM53ftI 
"Rick Astley interview on Richard \& Judy - part 2 ." YouTube video, 5:22, from an interview televised by Watch on March 5, 2009. Posted by "sexteta." March 9, 2009. http:// www.youtube.com/watch?v=JJZdtTHV_Sk

\section{Secondary Sources}

Aitken, Stuart C. "Culture and Representation." In The Routledge International Encyclopedia of Men and Masculinities, edited by Michael Flood, Judith Kegan Gardiner, Bob Pease, and Keith Pringle, London: Routledge, 2007, 120-23.

Beynon, John. Masculinities and Culture. Buckingham: Open University Press, 2002.

Cavanaugh, John C., and Fredda Blanchard-Fields. Adult Development and Aging ( $6^{\text {th }}$ edition). Belmont CA: Wadsworth, 2011.

Diamond, Michael J. "Masculinity and its discontents: Making room for the 'mother' inside the male - An essential achievement for healthy male gender identity." In Heterosexual Masculinities: Contemporary Perspectives from Psychoanalytic Gender Theory, edited by Bruce Reis and Robert Grossmark. London/New York: Routledge 2009, 23-53.

Erber, Joan T. Aging and Older Adulthood. Chichester, UK / Malden, MA: Wiley-Blackwell, 2010.

Erikson, Erik H. The Life Cycle Completed: A Review by Erik H. Erikson. New York: Norton, 1982.

Hawkins, Stan. The British Pop Dandy: Masculinity, Popular Music and Culture. Aldershot: Ashgate Publishing Limited, 2009.

Hearn, Jeff et al. The social problem of men: final report: Project HPSE-CT1999-00008. Vol. 1. Luxemburg: Office for Official Publications of the European Communities, 2004. http://ec.europa.eu/ research/social-sciences/pdf/socialproblemi_en.pdf < accessed 9 August, 2012>.

Here and Now. http://www.here-and-now.info/

Jarman-Ivens, Freya. “'Don't Cry, Daddy': The Degeneration of Elvis Presley's Musical Masculinity.” In Oh Boy! Masculinities and Popular Music, edited by Freya Jarman-Ivens. New York/Abingdon: Routledge, 2007, 161-180.

Kantor, Martin. Now That You're Out: The Challenges and Joys of Living As a Gay Man. Santa Barbara CA: Greenwood Publishing Group, 2011.

Handbook of Studies on Men and Masculinities, edited by Michael S. Kimmel, Jeff Hearn, and Robert W. Connell. London: Sage, 2005.

Lachman, Margie E. “Introduction.” In Handbook of Midlife Development, edited by Margie E. Lachman, xvii-xxvi. New York: John Wiley and Sons, 2001.

Lachman, Margie E. “Development in Midlife.” Annual Review of Psychology 55 (2004): 305-31.

Leonard, Marion. Gender in the Music Industry: Rock, Discourse and Girl Power. Ashgate: Aldershot/ Burlington VT, 2007.

Marshall, P. David. Celebrity and Power: Fame in Contemporary Culture. Minneapolis MN: University of Minnesota Press, 1997.

McAdams, Dan P. "Can personality change? Levels of stability and growth in personality across the lifespan." In Can Personality Change, edited by Todd Heatherton and Joel Weinberger.

Washington DC: American Psychological Association Press, 1994, 299-313.

McAdams, Dan P. "Narrating the self in adulthood." In Aging and biography: Explorations in adult development, edited by James E. Birren et al. New York: Springer, 1996, 131-48. 
McAdams, Dan P. “The psychology of life stories.” Review of General Psychology 5 (2001): 100-22.

McAdams, Dan P., and J.L. Pals. "A new Big Five: Fundamental principles for an integrative science of personality.” American Psychologist 61 (2006): 204-17.

Milestone, Katie and Anneke Meyer. Gender and Popular Culture. Cambridge UK / Malden MA: Polity, 2012.

Prono, Luca. Encyclopedia of Gay and Lesbian Popular Culture. Westport CT: Greenwood Press, 2008.

Rolph, David. Reputation, Celebrity and Defamation Law. Ashgate: Aldershot/Burlington VT, 2008.

Senelick, Laurence. The Changing Room: Sex, Drag and Theatre. London/New York: Routledge, 2000.

Stewart, Abigail. Personality in middle age: Gender, history and mid-course corrections. Murray Award Lecture presented at the American Psychological Association, Toronto, 1996.

Taylor, Jane. "What makes a good feature? The Different Genres." In Print Journalism: a critical introduction, edited by Richard Keeble. London/New York: Routledge, 2005, 117-28.

\section{NOTES}

1. Indeed, the emphasis of the tour on well-known songs rather than new material is stressed in press coverage. See Stuart Arnold, "Critics," The Northern Echo, December 18, 2004; Johnny Davis, "Never Gonna Give You Up," The Times, May 16, 2009; Diane Parkes, “Midge's pledge to play his hits," Birmingham Mail, January 14, 2011; Nigel Powlson, "Rick's never gonna give up," Derby Evening Telegraph, May 21, 2010; Jonathan Rennie, “Tony's just an old romantic at heart," Evening Times, April 18, 2002. For an example of a Here and Now setlist, see Mike Atkinson, "Here And Now tour, Nottingham Trent FM Arena, Friday May 9," Troubled Diva, 10 May, 2008, http://troubleddiva.com/2008_05_04_troubled-diva_archive.html\#5885785463623772144, accessed 13 August, 2012.

2. See "Here And Now," http://www.here-and-now.info/hn_biography.html and http:// www.here-and-now.info/hn_tours.html, accessed August 13, 2012.

3. For further discussion of the journalistic categories of "entertainment" and "human interest," see Jane Taylor, "What makes a good feature? The Different Genres," in Print Journalism: a critical introduction, ed. Richard Keeble (London/New York: Routledge, 2005), 122, 124-125.

4. See Marion Leonard, Gender in the Music Industry: Rock, Discourse and Girl Power (Ashgate: Aldershot/Burlington VT, 2007), 65-66.

5. Leonard, Gender in the Music Industry, 65.

6. Leonard, Gender in the Music Industry, 90.

7. Leonard, Gender in the Music Industry, 73.

8. As Margie E. Lachman comments, the age "boundaries for midlife are fuzzy with no clear demarcation [...] Those between the ages 40 and 60 are typically considered to be middle-aged, but there is at least a 10-year range on either end, so that it is not uncommon for some to consider middle age to begin at 30 and end at 75." See Margie E. Lachman, "Introduction," in Handbook of Midlife Development, ed. Margie E. Lachman (New York: John Wiley and Sons, 2001), xx, and Margie E. Lachman, “Development in Midlife," Annual Review of Psychology 55 (2004): 310-312.

9. See P. David Marshall, Celebrity and Power: Fame in Contemporary Culture Place (Minneapolis MN: University of Minnesota Press, 1997), X, and Taylor, “What makes a good feature?"125.

10. Stan Hawkins, The British Pop Dandy: Masculinity, Popular Music and Culture (Aldershot: Ashgate Publishing Limited, 2009), 20.

11. Hawkins, The British Pop Dandy, 118. 
12. Laurence Senelick, The Changing Room: Sex, Drag and Theatre (London/New York: Routledge, 2000), 417.

13. See Senelick, The Changing Room, 417 and also Luca Prono, Encyclopedia of Gay and Lesbian Popular Culture (Westport CT: Greenwood Press, 2008), 39-41.

14. David Rolph, Reputation, Celebrity and Defamation Law (Ashgate: Aldershot/Burlington VT, 2008), 143-46.

15. Aidan Radnedge, "Neighbour moves on; Jason Donovan puts the 80 s behind him - after trip down memory lane," Metro, October 8, 2010.

16. Dawn Collinson, “The King of Rick 'n' roll,” Liverpool Echo, January 30, 2009.

17. Simon Wilson, "Interview: Rick Astley," Nottingham Evening Post, January 23, 2009; and Simon Wilson, "Interview: Kim Wilde," Nottingham Evening Post, May 1, 2009.

18. Laura Davis, "If you don't like it then just quit," Daily Post (Liverpool), April 3, 2009.

19. Johnny Davis, "Never Gonna Give You Up."

20. Simon Button, "Toyah Willcox is back on the road and singing new songs but that doesn't make her a has-been," The Express, February 11, 2002; and Louise Rimmer, "It's a mystery but no new song required as the Eighties turns to gold," Scotland on Sunday, April 28, 2002.

21. Davis, "If you don't like it then just quit."

22. "Never gonna regret giving up fame," Sunday Sun, February 24, 2008.

23. "Never gonna regret giving up fame."

24. Natalie Anglesey, "Family is Rick's priority," Manchester Evening News, July 20, 2011.

25. Emma Pinch, "I still get a tingle from singing," Daily Post (Liverpool), May 13, 2008.

26. Gail Henderson, "Gail Meets Jason Donovan,” The Sunday Life, November 7, 2010.

27. Spencer Bright, "My life hasn't always been a disaster but when it has, it's been spectacular!" Daily Mail, June 10, 2011.

28. Bright, "My life hasn't always been a disaster".

29. Bright, "My life hasn't always been a disaster"; see also Mike Atkinson, "Interview: Boy George," Nottingham Evening Post, January 9, 2009.

30. Anuji Varma, "I'm sorry... by George," Sunday Mercury, October 12, 2008.

31. Tim Fletcher, "Drugs, prison, pop - and a boy that's finally grown up," Burton Mail, November 12, 2010.

32. Michael J. Diamond, "Masculinity and its discontents: Making room for the 'mother' inside the male - An essential achievement for healthy male gender identity," in Heterosexual Masculinities: Contemporary Perspectives from Psychoanalytic Gender Theory, ed. Bruce Reis and Robert Grossmark (London/New York: Routledge 2009), 44.

33. Andy Coleman, "George not fazed by 50th birthday," Birmingham Mail, June 24, 2011.

34. Bright, "My life hasn't always been a disaster."

35. Coleman, "George not fazed by 50 th birthday."

36. Bright, "My life hasn't always been a disaster."

37. See Dan P. McAdams, "Narrating the self in adulthood," in Aging and biography: Explorations in adult development, ed. James E. Birren et al. (New York: Springer, 1996), 131-148.; Dan P. McAdams, “The psychology of life stories," Review of General Psychology 5 (2001): 100-22; and Dan P. McAdams, and J.L. Pals, "A new Big Five: Fundamental principles for an integrative science of personality," American Psychologist 61 (2006): 204-17. For further discussion of McAdams's LifeStory model, see John C. Cavanaugh and Fredda Blanchard-Fields, Adult Development and Aging (Belmont CA: Wadsworth, 2011), 338-40, and Joan T. Erber, Aging and Older Adulthood (Chichester, UK / Malden, MA: Wiley-Blackwell, 2010), 242.

38. Cavanaugh and Blanchard-Fields, Adult Development and Aging, 337.

39. Martin Kantor, Now That You're Out: The Challenges and Joys of Living As a Gay Man (Santa Barbara CA: Greenwood Publishing Group, 2011), 110. 
40. Katie Milestone and Anneke Meyer, Gender and Popular Culture (Cambridge UK / Malden MA: Polity, 2012), 114.

41. "Jason's Happy to Revisit the 80s," Coventry Evening Telegraph, June 24, 2011; see also Catherine Jones, "Jason Donovan talks The War of the Worlds and takes a look back at the 80s," Liverpool Echo, November 19, 2010.

42. "Eg interview: Boy George," Nottingham Evening Post, February 1, 2008.

43. Sean Michaels, "Boy George to reunite Culture Club in 2012," The Guardian, January 29, 2011.

44. "Eg interview: Boy George."

45. "Eg interview: Boy George."

46. Diamond, "Masculinity and its discontents," 44.

47. "Never gonna give him up," Nottingham Evening Post, May 7, 2009.

48. Pinch, "I still get a tingle from singing."

49. Powlson, "Rick's never gonna give up."

50. "Rick Astley writing movie musical," Guardian Unlimited, February 2, 2009.

51. "Everything is still rosy in Donovan's garden," Solihull News, April 29, 2011.

52. "Eg interview: Boy George."

53. Atkinson, "Interview: Boy George."

54. Powlson, "Rick's never gonna give up."

55. Henderson, "Gail Meets Jason Donovan."

56. "Carole's life is on a roll," Sunday Mercury, October 7, 2001; Jill Foster, "CD reviews and music: heaven to hell," Daily Mirror, July 30, 2004; “Kim Wilde keeps hangin' on," Derby Evening Telegraph, February 20, 2009; and Powlson, "Rick's never gonna give up."

57. Davis, "Never Gonna Give You Up."

58. Pinch, "I still get a tingle from singing."

59. Davis, "If you don't like it then just quit."

60. "Showbiz: Rick pads up," Sunday Mercury, November 18, 2007.

61. See Davis, "If you don't like it then just quit;" and also Collinson, "The King of Rick 'n' roll," who refers to "a typically self-effacing comment from a man [Astley] who, despite more than 20 years of fame, has never felt truly at ease in the spotlight."

62. Fletcher, "Drugs, prison, pop."

63. Gavin Allen, "Return of the one and only," South Wales Echo, April 7, 2009; Davis, "Never Gonna Give You Up." and Aidan Smith, “Accepting the Eighties," The Scotsman, July 18, 2011.

64. "She's the real wilde child," Nottingham Evening Post, April 2, 2009.

65. Milestone and Meyer, Gender and Popular Culture, 114.

66. Alongside the "new man as nurturer" also developed the "new man as narcissist," John Beynon, Masculinities and Culture (Buckingham: Open University Press, 2002), 100-105, and Milestone and Meyer, Gender and Popular Culture, 116.

67. See Diamond, "Masculinity and its discontents...," 44; and also, with reference to Jung and Erber, Aging and Older Adulthood, 237.

68. Cavanaugh and Blanchard-Fields, Adult Development and Aging, 329-30.

69. "Everything is still rosy in Donovan's garden."

70. Lorraine Kelly, "He'd Don So Well," The Sun, October 9, 2010.

71. Henderson, "Gail Meets Jason Donovan."

72. Pinch, "I still get a tingle from singing."

73. "Eg interview: Rick Astley," Nottingham Evening Post, April 4, 2008.

74. Anglesey, "Family is Rick's priority."

75. Pinch, "I still get a tingle from singing."

76. Sophie Heawood, “Are we ever gonna give him up?” The Times, January 30, 2009.

77. Milestone and Meyer, Gender and Popular Culture, 116.

78. "Eg interview: Rick Astley." 
79. Anglesey, "Family is Rick's priority."

80. Diamond, "Masculinity and its discontents," 44.

81. Michael S. Kimmel, Jeff Hearn, and Robert W. Connell eds, Handbook of Studies on Men and Masculinities (London: Sage, 2005), 3.

82. See Jeff Hearn et al., The social problem of men: final report: Project HPSE-CT1999-00008. Vol. 1, Luxemburg: Office for Official Publications of the European Communities, 2004, 80-82. http:// ec.europa.eu/research/social-sciences/pdf/socialproblemi_en.pdf

83. Erber, Aging and Older Adulthood, 243-51.

84. Leonard, Gender in the Music Industry, 106.

85. December 2006-July 2011, Factiva database <accessed July 16 and 17, 2011>.

86. Stuart C. Aitken, "Culture and Representation," in The Routledge International Encyclopedia of Men and Masculinities, eds Michael Flood, Judith Kegan Gardiner, Bob Pease, and Keith Pringle (London: Routledge, 2007), 120.

\section{ABSTRACTS}

This article shows how newspaper coverage of British musicians associated with the Here and Now 1980s nostalgia shows, particularly Boy George, Jason Donovan and Rick Astley, serves effectively to promote a range of approaches to midlife masculinities. While traditional masculinities are maintained in terms of rationality and developed through discourses of midlife maturity, they are also challenged through the importance attached to emotion and sensitivity, a reduction in work-related competitiveness and the expression of a more detached, light-hearted, even flippant, attitude. Certain 'new' masculinities, which gained currency during the 1980s, are also in evidence. Indeed, there is a particular emphasis on fathers-as-nurturers and on equality in heterosexual partnerships.

\section{INDEX}

Keywords: masculinities, midlife, newspaper, popular music, nostalgia

\section{AUTHOR}

\section{CHRIS TINKER}

Chris Tinker is Reader in French at Heriot-Watt University, Edinburgh. He has research interests in the development of popular music and media cultures in France and Britain since the 1960s, and is author of Georges Brassens and Jacques Brel: Personal and Social Narratives in Post-war Chanson and Mixed Messages: Youth Magazine Discourse and Sociocultural Shifts in Salut les copains (1962-1976). 